\title{
Implementation of Sq4r Model to Increase Reading Comprehension Ability of Elementary Students
}

\author{
Naeklan Simbolon ${ }^{\mathrm{a}}$, Inrasari Marbun ${ }^{\mathrm{b}}$ \\ Faculty of Education, Medan State University \\ Corresponding email: naeklan@unimed.ac.id, inrasarimarbun@gmail.com
}

\begin{abstract}
This research aims to improve students' reading comprehension ability by using SQ4R model (Survey, Question, Read, Reflect, Recite, Review) in fifth Grade. This research was conducted at SDN Medan Johor. Subjects were 30 students. This research was conducted in two cycles. In each cycle carried out the stages of planning, implementation, observation and reflection. Data collection techniques used are tests and observations. The test is used to determine students' reading comprehension. Observation is done to know the activeness of students in following the lesson, students' ability in expressing opinions and knowing the level of students' understanding of the material given. The results of the research on the initial test level reading ability of students with an average score of 56.16. In the first cycle with an average scre of 69.66. In the second cycle obtained classical completeness level with an average score of 80.83. Using the SQ4R learning model can improve students' reading comprehension skills in Indonesian subjects. Thus, it is suggested that teachers use SQ4R in learning in fifth grade of elementary school.
\end{abstract}

Keywords: Reading Comprehension, Learning Model, SQ4R, Indonesian Subject

\section{INTRODUCTION}

Quality education is a major factor for the advancement of science knowledge of a nation. Through quality education is possible the birth of science that will produce superior products that have competitiveness at global level. Quality education will give birth to highly competitive human resources. Learning to read in Primary School is very influential in learning Indonesian language. Tarigan (2008: 58) argues that reading purpose is for understanding; some reading that aims to understand: 1) standards or literary standards, 2) critical review, 3) drama (printed drama), 4) patterns of fiction.

Through teacher reading learning can develop students' moral values, reasoning abilities, and creativity. This shows the importance of mastery of reading ability as one of the standard of language ability, which must be achieved in every level of education. The ability to read is the main basis not only for teaching Indonesian, but also for teaching other subjects. Understanding the content of the reading is the ultimate goal of reading. Dalman (2013: 87) suggests that reading comprehension is cognitive reading (reading for understanding). According Samsu Somadayo (2011: 11), the main purpose of reading comprehension is to gain understanding. Reading comprehension is a reading activity that seeks to comprehend the text: 1) the ability to grasp the meaning of words and expressions used by the author, 2) the ability to grasp explicit meaning and implied meaning, 3) the ability to make conclusions.

Turner in Alexander states that one can be said to understand the reading well if he can (1) recognize the words or sentences in the reading or know their meaning, (2) to connect the connotative and denotative meaning both to the meaning contained in the reading, (3) to know the whole meaning or its perception of the meaning contextually, and (4) make consideration of the value of the reading content based on his experience. Turner further explains that reading includes two basic skills, (1) predictive meaning skills, and (2) skills to understand and use as efficiently. Indicators related to reading comprehension include: (1) information in the form of facts, definitions, or concepts. (2) the meaning of the word or phrase, (3) the discourse organization of the main idea, and the explanatory Sentence, (5) the theme or topic and Title of discourse, (6) draws the essence/conclusions about things, concepts, problems or opinions. Pearson and Johnson (in Burns, Roe and Ross) states that reading 
comprehension is limited as a unified process and a series of distinctive processes.

According to Palinesar et al (in Farris) in reading comprehension there are three important parts, namely (1) an active constructive process, (2) thought processes before, during, and after reading, and (3) interaction between reader, text, and context. In this connection Anderson and Armbruster (in Farris) explain that when the reader interprets a text, the reader summons the stored knowledge associated with the topic of the text being read.

Based on the characteristics and indicators of the ability to read the above understanding, it can be concluded that the ability of students in reading comprehension is indicated by: (1) ability to capture discourse contents either explicitly or implicitly, (2) ability to answer questions according to discourse content, (3) ability Summarize the contents of the discourse by finding the main idea in each paragraph, (4) the ability of students to conclude and retell the contents of the discourse with their own sentences with a cascading language. But the reality is that not all students can achieve that goal. Many students are able to read fluently a reading material, but do not understand the content of reading texts that are read. Reading comprehension is one aspect of language skills that must be mastered by elementary school students, especially for students in high-class level. Such reading and learning makes students less able to listen to the reading well and can not understand the reading evenly so that when asked the students are unable to answer fluently. Furthermore, the problems encountered, teachers only focus on textbooks and during the learning process does not appear any question and answer activities, students tend to be passive when learning takes place. Because less activity involving students to be active makes students feel that reading comprehension learning is a less interesting and boring reading learning.

Learning reading comprehension can be an interesting and fun learning if the learning process is applied appropriately for reading learning. Learning should be able to provide opportunities for students, so that students can directly participate in learning. In reading it is very important for the students to know the extent to which students understand the reading material read and for the teacher to know to where the students understanding of the material being studied. Therefore, it is necessary to use innovative and interesting learning models for students applied by Indonesian language teachers that lead to active student involvement in learning with the SQ4R model (Survey, Question, Read, Reflect, Recite, Review).

SQ4R is an extension of the SQ3R method which is a specific tip designed to understand the content of the text developed by Francis P. Robinson at Ohio State University of the United States. SQ3R stands for Survey, Question, Read, Recite and Review. Rhonda and Debbie put forward another reading and study plan is called SQ4R. It includes all the steps in SQ3R of Survey, Question, Read, Recite, and Review. But it also adds a fourth R: Write. In this last step, you write about what you read. Trianto (Risky Ananda 2015: 10) reveals that the SQ4R learning model can be interpreted as a conceptual framework that describes a systematic procedure by organizing learning experiences to achieve a specific goal.

\section{METHODS}

This research is a Classroom Action Research which leads to the improvement of students' reading comprehension on Indonesian language subjects in grade V SDN Medan Johor students. This study was conducted on the even semester of the academic year 2016/2017 i.e. from January to March 2017. This research uses Kemnis \& Mc Model design. Tagart (Arikunto, 2010: 137). Broadly speaking there are two cycles in classroom action research, and each cycle has four stages: 1) planning, 2) implementation, 3) observation, 4) reflection.

\section{Planning}

At the planning stage several researchers held meetings with classroom teachers to discuss classroom action research implementation techniques. In the meeting the curriculum is reviewed as a reference for the material, among others: 1. Develop a plan of implementation of learning along with the test in accordance with English learning materials, preparing materials, tools, learning media needed during the learning process, preparing English text reading material to be read and observed by students In accordance with the purpose of learning, making questions that will be submitted to students based on the competencies studied, preparing the evaluation tool (pre-test, post-test, and worksheet). Prepare the instrument in the form 
of observation sheet of student and teacher activities.

\section{Implementation}

At this stage that is done in the learning process SQ4R in the learning process. The teacher gives the reading text according to the material and the competence to be achieved for reading. Teacher asks students to observe the reading by recording or marking the keywords by the students. Creating questions that are based on reasing.Provide assignments to students to read and respond to questions that have been previously arranged by swapping with a partner. Marking things that are understood or making small notes from reading by students to solve problems/informed material based on reading. Providing/informing material that is on material already read in their own words. Considering the answers given (note-togethertogether). Review the overall student answers to ensure students have a complete picture of the reading. In the closing activities held a reflection.

\section{Observation}

This stage is carried out simultaneously with the implementation of class action using the observation sheet provided. This observation was done by teacher of class $\mathrm{V}$ SDN. Activities conducted to determine the activity of students in following the lesson, the ability of students in expressing opinions and know the level of students' understanding of the material provided. In addition, this activity is also to know the suitability of the action with the plan that has been prepared to see how far the implementation of the action can produce the changes as expected.

\section{Reflection}

Reflection activity is done to see how far progress through test and observation have been done. This reflection is implemented to reinforce what has been done to see the suitability achieved with the expected in reading learning that ultimately found a deficiency to be improved. Reflection is implemented by looking at student learning outcomes based on student test result data with student activity.

\section{RESULTS AND DISCUSSION}

\section{Research Result}

Description of research results are as follows: At the initial meeting students were given pre test as much as 20 items about multiple choice. Initial tests are given to the students prior to implementing the action plan to determine the students' initial ability to read understanding through answering questions in accordance with the text readings and without seeing text reading at the time of answering questions.

Some things still need to be improved by the researcher such as, the ability of the researcher to convey the learning objectives is still less effective, giving motivation to the students to be creative that is still unclear, explaining the learning steps with SQ4R model is still unclear, guiding the students in relaying the contents Readings are still less clear, providing opportunities for students to ask and comment is still less evenly for all students, summarize the learning activities that have been implemented also still less evenly for the students. Meanwhile, in the first meeting of student involvement in learning with sufficient category acquisition.

Students begin to be active at the time of learning and some students begin to be asked to discuss with friends. However, some things still need to be observed and guided by the researchers in the next meeting such as making and answering questions as the text reading is still lacking. In addition to commenting or asking students who are sometimes not in accordance with the text reading, and time efficiency in making questions, answer questions in the discussion many students still need guidance and direction from researchers.

Based on the observations made by the observer in the first cycle with two meetings, that the action of the researcher has not been optimal or categorized quite well and the students are not accustomed using the learning model. Researchers' actions that have not been optimal can be seen from the results of the first test post.

When directed to cooperate with his teammates to exchange questions with his classmates, some students refuse to do so with shame or displeasure with their coworkers. Another thing that is lacking in the implementation of the SQ4R learning model when the teacher asks the students to make the essence of the text is not entirely able to create the essence of the essay that ends by writing the entire text of the text and when asked to write the main idea in the future most students refused and did not want to answer in front of the class. As a result teachers can not use time efficiently and effectively in learning 
because in this case the teacher provides directors and motivation for students more active, not shy and confident as learning takes place.

Based on the data analysis that has been done by the researcher can state that the SQ4R learning model shows that there is a slight increase of students' comprehension ability to the text of reading. Based on the results of the study can be seen that students who are able to read comprehension on the initial test as many as 8 students with a percentage of $26.66 \%$ completeness, the first cycle as many as 20 students with a percentage completeness $69.66 \%$, and in the second cycle as many as 26 students with percentage completeness $86.66 \%$. Thus it can be concluded that with the SQ4R model in the process of reading reading text reading can increase students' reading comprehension in grade $\mathrm{V}$ SD. For more details, improving students' reading comprehension can be seen in the table below:

Table 1. Recapitulation of Pre-Test Value, Cycle I, Cycle II

\begin{tabular}{ccccc}
\hline No & $\begin{array}{c}\text { Implementatio } \\
\text { n Phase }\end{array}$ & $\begin{array}{c}\text { The } \\
\text { number } \\
\text { of } \\
\text { student } \\
\text { s who } \\
\text { capable }\end{array}$ & $\begin{array}{c}\text { Averag } \\
\text { e Score }\end{array}$ & $\begin{array}{c}\text { Percentage } \\
\text { of } \\
\text { completenes } \\
\text { s }\end{array}$ \\
& Pre Test & 8 & 53 & $26,66 \%$ \\
1. & Post Test I & 20 & 69,66 & $69,66 \%$ \\
2. & Post Test II & 26 & 80,83 & $86,66 \%$ \\
\hline 3. & & &
\end{tabular}

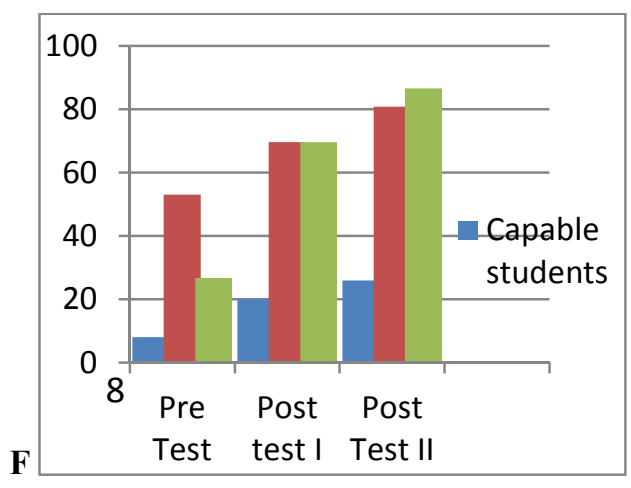

Figure 1.1 Graph of Achievement of Pre Test Results, Post Test I, Post Test II

\section{Discussion}

Based on the results of research conducted during the learning process, it can be concluded that the SQ4R model (Survey, Question, Read, Reflect, Recite, Review) can improve students' reading comprehension in grade V Elementary School. Thus, it can be concluded that students' reading comprehension ability with SQ4R model can be improved even though learning with SQ4R model can be used as an alternative in reading comprehension of a reading text. This is in line with the results of previous research conducted (Herlina, 2016) entitled: Improve Reading Ability Understanding English Through SQ4R Method. The result of the research shows that there is an increase of reading comprehension in English with SQ4R method shown from the data obtained from the reading comprehension test of the students who got the score $\geq 75$ in the first cycle $55,55 \%$ and the second cycle is $83,33 \%$. Furthermore, research conducted by Ernawati Nasir entitled: Efforts to Improve Reading Ability Understanding With Approach Process Skills In Students Class V SDN Sabelak Kecamatan Bulagi Selatan. His research shows that there is an increase in students 'reading comprehension from the preaction result of the students' initial data which is complete category of three people or percentage of classical completeness 20 percent. In the first cycle of complete students is seven people, while the percentage of classical completeness 46.66 percent. While the second cycle of the number of completed students is 14 people, the percentage of classical completeness 93.32 percent.

In addition, previous research conducted by (Adnyana Putras, 2013), entitled Influence Learning Model SQ4R to Reading Skills In Learning Indonesian Grade $\mathrm{V}$ Elementary School SD Gugus I South Denpasar. The result of the research shows that there is significant difference of reading skill of Indonesian language learning between students who implement SQ4R learning model with students who implement learning using conventional learning (tct $=7,139$; ttable $=2,000)$, meaning the mean of reading skill which is learned by the application of the SQ4R learning model is higher than that of students taught by conventional learning $(81,48>75,84)$. With the SQ4R model, students can be more motivated and more active because of the activity of reading activities that make students directly involved. Besides reading activities for students is no longer boring and learning is not only centered on the teacher. This can be seen from the results of observation analysis that with the implementation of SQ4R model can be seen that in the first cycle of the first meeting the average involvement of 2.1 students with less categories, then at the second meeting increased by an average of 2.28 good categories. In the second cycle of the first 
meeting the average student involvement reached 2.57 categories well then at the second meeting increased by an average of 3.14 and entered the good category.

Based on research activities conducted by researchers during the learning process, it can be concluded that the SQ4R model (Survey, Question, Read, Reflect, Recite, Review) can improve students' reading comprehension in grade $\mathrm{V}$ primary school.

\section{CONCLUSION}

Based on the research, the following conclusions can be drawn: First, using Survey, Question, Read, Reflect, Recite, Review (SQ4R) models can improve students' reading comprehension in grade V Primary School. Active and able to achieve the value of KKM. Second, the results of student observation during the learning process with the SQ4R model took place from the aspect of student involvement also experienced an increase in the first cycle of the first meeting the average involvement of students of the category less, then at the second meeting increased with good category. In the second cycle of the first meeting the average student engagement reached the good category then at the second meeting increased by an average of 3.14 and entered the good category. In relation to previous research supporting this research, the SQ4R learning model is very well used in learning.

\section{REFERENCES}

[1] Alexander, J.E. (Ed.). 1988 Teaching Reading. Boston: Scott, Foresman, and Company.

[2] Ananda, Risky. 2015. Pengaruh Penggunaan Model Pembelajaran SQ4R (Survey, Question, Read, Reflect, Recite, Review) Pada Pelajaran IPS Sejarah Terhadap Hasil Belajar Siswa Kelas VII SMP Empu Tantular Semarang Tahun Pelajaran

$2014 / 2015$. lib.unnes.ac.id/20878/1/3101411090-

S.pdf.

[3] Aqib.Zainal, dkk. 2010. Penelitian Tindakan Kelas. Bandung: Yrama Widya.

[4] Atkinson, Rhonda Holt, and, Longman, Debbie Guice. 2006. Reading Strategies for Today's College Student. Boston: Thomson Wadsworth.

[5] Burns, Paul C., Betty D. Roe, dan Elinor P. 1996. Ross. Teaching Reading in Today's Elementary Schools. Boston: Houghton Mifflin.

[6] Dalman. 2013. Ketrampilan Membaca. Jakarta: Raja Grafindo Persada.

[7] Dewi, Rosmala. 2015. Profesionalisasi Guru Melalui Penelitian Tindakan Kelas. Medan: Unimed Press.

[8] Farris, Pamela J. 1993. Language Arts a Process Approach. Illionis: Brown \& Benchmark Publishing.

[9] Herlina. 2016. Meningkatkan Kemampuan Membaca Pemahaman Bahasa Inggris Melalui Metode SQ4R, Visi PPTK PAUDNI, vol 11, no.1.

[10]Nasir, Ernawati. Upaya Meningkatkan Kemampuan Membaca Pemahaman Dengan Pendekatan Ketrampilan Proses Pada Siswa Kelas V SDN Sabelak Kecamatan Bulagi Selatan, Kreatif Tadulako, vol 5, no 9

[11] Putras, Adnyana. 2013. "Pengaruh Model Pembelajaran SQ4R terhadap Keterampilan Membaca Dalam Pembelajaran Bahasa Indonesia Siswa Kelas V SD Gugus I Denpasar Selatan"

[12] Somadayo, Samsu. 2011. Strategi dan Teknik Pembelajaran Membaca. Yogyakarta: Graha Ilmu.

[13] Sudjana, Nana. 2009. Penilaian Hasil Proses Belajar Mengajar.Bandung: Remaja Rosdakarya

[14] Tarigan. 2008. Membaca Sebagai Suatu Ketrampilan Berbahasa. Bandung: Angkasa.

[15] Trianto.2011. Mendesain Model Pembelajaran Inovatif - Progresif. Jakarta: Kencana Perdana Media Group. 